\title{
マスト細胞研究の新たな展開
}

\author{
田中智之, ${ }^{*}, a$ 西田圭吾 $b$
}

\section{Recent Advances in Mast Cell Research}

\author{
Satoshi TANAKA ${ }^{*, a}$ and Keigo NISHIDA ${ }^{b}$ \\ ${ }^{a}$ Division of Pharmaceutical Sciences, Graduate School of Medicine, Dentistry, and Pharmaceutical Sciences, \\ Okayama University, 1-1-1 Tsushima-naka, Kita-ku, Okayama 700-8530, Japan, and ${ }^{b}$ Laboratory \\ for Cytokine Signaling, RIKEN Research Center for Allergy and Immunology, \\ 1-7-22 Suehiro-cho, Tsurumi-ku, Yokohama 230-0045, Japan
}

塩基性のアニリン色素による染色によって Ehrich が結合組織においてマスト細胞を見い出し てから 130 年以上が経過した. ${ }^{1)}$ マスト細胞はその 後長い間機能不明の細胞であったが，ヒスタミンが マスト細胞の顆粒に貯留され，アナフィラキシー応 答の際には顆粒から細胞外へと放出されることが 1950 年代中頃に明らかとなり，一躍「アレルギー」 における主要なエフェクター細胞として注目を集め るようになつた。 ${ }^{2)} 1974$ 年には，ラットマスト細胞 株に IgEが結合することが示され, ${ }^{3)}$ Ishizaka らに よって見い出された IgE を介する即時型アレル ギー4)とマスト細胞とのリンクが明らかにされた. 1980 年代には, 寄生虫感染時に消化管粘膜にマス 卜細胞が誘導されることが見い出され，寄生虫感染 防御における重要な生体防御因子としての研究が進 展した. ${ }^{5)}$ 現在に至るまでマスト細胞は「即時型ア レルギー」と「寄生虫感染防御」に係わる細胞とし て認識されてきたが, 近年の研究の進展を通じてそ の新たな機能が次々と見い出されており（Table 1), マスト細胞研究は次の段階に入ろうとしてい る。例えば, 最近の疾患モデルを用いた研究によ り, 多発性硬化症や関節炎などの慢性的な免疫疾患 に関与することが示され，こうした従来精確に解析 することが困難であった免疫反応におけるマスト細

$a$ 岡山大学大学院医歯薬学総合研究科 (薬学系) 生体機 能化学（干700-8530 岡山市北区津島中 1-1-1), b独立 行政法人理化学研究所免疫・アレルギー科学総合研究 センターサイトカイン制御研究グループ（テ230-0045 横浜市鶴見区未広町 1 丁目 7 番 22 号)

*e-mail: tanaka@pharm.okayama-u.ac.jp

日本薬学会第 130 年会シンポジウム S53 序文
胞の重要性が再認識されている。また，エネルギー 代謝や血圧調節といつたマスト細胞との関連が予想 されなかつた領域における機能の報告にも注目が寄 せられている.

こうした背景の下, 日本薬学会第 130 年会シンポ ジウムにおいて「マスト細胞研究の新たな展開」と いうタイトルで, 国際的に活躍する研究者による最 新の知見の紹介と展望が発表された.

シンポジウムの冒頭では，マスト細胞の機能，最 近の研究, そして研究手法について田中（岡山大 院・医歯薬）が紹介を行った，筆者らは，マス卜細 胞研究の今後の展開を考える上で重要なポイントは 以下の 2 点と考えている. 1 点目は，マスト細胞は 非常に幅広い刺激に対する受容システムを有してお り，環境の変化をいち早く察知する局所環境のセン

Table 1. Recently Identified Novel Functions of Mast Cells

\begin{tabular}{ll}
\hline \hline \multicolumn{1}{c}{ Functions } & \multicolumn{1}{c}{ References } \\
\hline $\begin{array}{l}\text { MHC class I-mediated cross presenta- } \\
\text { tion }\end{array}$ & $\begin{array}{l}\text { Stelekati E. } \text { et al. } \\
(2009)^{6)}\end{array}$ \\
$\begin{array}{l}\text { Induction of MHC class II molecules } \\
\text { and antigen presentation }\end{array}$ & $\begin{array}{l}\text { Kambayashi T. et al. } \\
(2009)^{7)}\end{array}$ \\
$\begin{array}{l}\text { Promotion of diet-induced obesity and } \\
\text { diabetic changes }\end{array}$ & Liu J. et al. $(2009)^{8)}$ \\
$\begin{array}{l}\text { IL-10-mediated suppression of inflam- } \\
\text { matory responses }\end{array}$ & $\begin{array}{l}\text { Grimbaldeston M. A. } \\
\text { et al. }(2007)^{9)}\end{array}$ \\
$\begin{array}{l}\text { Promotion of atherosclerosis } \\
\text { Supportive roles in Treg-mediated im- } \\
\text { mune tolerance }\end{array}$ & $\begin{array}{l}\text { Sun J. et al. }(2007)^{10)} \\
(2006)^{11)}\end{array}$ \\
$\begin{array}{l}\text { Local angiotensin formation through } \\
\text { renin release }\end{array}$ & $\begin{array}{l}\text { Mackins C. J. et al. } \\
\left.(2006)^{12}\right)\end{array}$ \\
$\begin{array}{l}\text { Limiting of endothelin-1-induced tox- } \\
\text { icity }\end{array}$ & $\begin{array}{l}\text { Maurer M. et al. } \\
(2004)^{13)}\end{array}$ \\
\hline
\end{tabular}


サーとしての特徴を持つことである。マスト細胞を 刺激するのはアレルゲンだけではなく，微生物産物 や神経ペプチド，サイトカイン，ホルモン，脂質メ ディエーター, 生理活性アミン, 物理化学的なス卜 レスなど，実に多彩である。また，一方でマスト細 胞は脱顆粒応答を通じて生理活性アミンやプロテ アーゼを放出するのみならず，アラキドン酸代謝物 や増殖因子，サイトカイン，ケモカインといったメ ディエーターを新たに合成，放出する，組織に常駐 するマスト細胞がこうした特質を持つことは，この 細胞が局所環境のホメオスタシスの維持に関与する ことを示唆するものであり，それが破綻することが 様々な疾患の背景にあると考えられる，2点目は， マスト細胞の分布組織に依存した機能の多様性であ り，この点に留意した研究を行う必要があることで ある，Kitamura らはマスト細胞が造血幹細胞に由 来することを見い出したが, ${ }^{14)}$ 循環血中にはマスト 細胞の性質を満たす細胞は検出されない。すなわ ち，マスト細胞の最終分化は分布する組織へと前駆 細胞が浸潤した後に起こると考えられる。このこと はマスト細胞が分化過程で周辺の微小環境の影響を 受けることを示している，従来のマスト細胞研究で は，がん化マスト細胞や，骨髄由来初代培養マスト 細胞がモデルとして用いられてきたが，こうした培 養細胞は組織内の成熟マスト細胞の性質を十分には 反映していない，近年ではマスト細胞を遺伝的に欠 くマウスに骨䯣由来初代培養マスト細胞を移植する ことにより得られる再構成モデルを通じて, 組織マ スト細胞の機能が明らかにされることが多い.

以下, 講演の順に従いシンポジウムの概要を紹介 する．田中は，皮膚型マスト細胞のモデル培養系の 確立と，それを用いた解析を報告し，マスト細胞に 発現するヒアルロン酸受容体 CD44 が皮膚組織にお けるマスト細胞数の制御に係わることを報告した。 武富芳隆先生（都臨床研）は，分泌型ホスホリパー ゼ $\mathrm{A}_{2}$ の遺伝子欠損マウスを用いた解析を中心に, マスト細胞の機能・分化制御が脂質ネットワークに よりいかに制御されるかについて講演された。西田 （理研・免疫・アレルギー）は，亜鉛トランスポー ターであるZnt5/Slc30a5 がマスト細胞に高発現 し，抗原刺激によるサイトカイン産生に係わるこ と, 及びその遺伝子欠損マウスでは遅延型アレル ギー応答，及びサイトカイン産生が減弱しているこ
とを報告した。中江 進先生（東大・医科研）は， 一般的には Th2 型の免疫応答が優位であると考え られている喘息において，炎症性サイトカインであ る Th17 の産生を特徵とする Th17 型の免疫応答が 優位であるタイプに関する解析結果を紹介され， Th17 細胞によるマスト細胞活性化と喘息の病態形 成との係わりを講演された。岡山吉道先生（日本大 院・医）は，ヒトマスト細胞における FceRI 受容 体 $\beta$ 鎖に関する解析結果をご紹介され，アレル ギー患者ではマスト細胞における $\beta$ 鎖の発現が有 意に増加していることを示した。一方， $\beta$ 鎖を欠く マスト細胞は FceRI の発現低下を示し，刺激によ る活性化レベルも低下することを報告された.

本誌上シンポジウムでは，武富先生と筆者らが, 講演内容に加えて, 周辺領域の進展や最新の知見を 紹介している。近年再び注目を集めているマスト細 胞に関する知見のアップデートの一助となれば幸い である。

\section{REFERENCES}

1) Ehrich P., Arch. mikr. Anat., 13, 263-277 (1877).

2) Riley J. F., "The Mast Cells," E. \& S. Livingstone, Edinburgh and London, 1959.

3) Kulczycki A., Isersky C., Metzger H., J. Exp. Med., 139, 600-616 (1974).

4) Ishizaka K., Ishizaka T., J. Immunol., 99, 1187-1198 (1967).

5) Woodbury R. G., Miller R. P., Huntley J. F., Newlands G. F. J., Palliser A. C., Wakelin D., Nature, 312, 450-452 (1984).

6) Stelekati E., Bahri R., D’Orlando O., Orinska Z., Mittrücker H. W., Langenhaun R., Glatzel M., Bollinger A., Paus R., Bulfone-Paus S., Immunity, 31, 665-676 (2009) .

7) Kambayashi T., Allenspach E. J., Chang J. T., Zou T., Shoag J. E., Reiner S. L., Caton A. J., Koretzky G. A., J. Immunol., 182, 4686 -4695 (2009).

8) Liu J., Divoux A., Sun J., Zhang J., Clément K., Glickman J. N., Sukhova G. K., Wolters P. J., Du J., Gorgun C. Z., Doria A., Libby P., Blumberg R. S., Kahn B. B., Hotamisligil G. S., Shi G. P., Nat. Med., 15, 940-945 (2009).

9) Grimbaldeston M. A., Nakae S., Kalesnikoff 
J., Tsai M., Galli S. J., Nat. Immunol., 8, 1095-1104 (2007).

10) Sun J., Sukhova G. K., Wolters P. J., Yang M., Kitamoto S., Libby P., Macfarlane L. A., Clair J. M., Shi G. P., Nat. Med., 13, 719-724 (2007).

11) Lu L. F., Lind E. F., Gondek D. C., Bennett K. A., Gleeson M. W., Pino-Lagos K., Scott Z. A., Coyle A. J., Reed J. L., Van Snick J., Strom T. B., Zheng X. X., Noelle R. J., Na- ture, 442, 997-1002 (2006).

12) Mackins C. J., Kano S., Seyedi N., Schäfer U., Reid A. C., Machida T., Silver R. B., Levi R., J. Clin. Invest., 116, 1063-1070 (2006) .

13) Maurer M., Wedemeyer J., Metz M., Piliponsky A. M., Weller K., Chatterjea D., Clouthier D. E., Yanagisawa M. M., Tsai M., Galli S. J., Nature, 432, 512-516 (2004).

14) Kitamura Y., Shimada M., Hatanaka K., Miyano Y., Nature, 268, 442-443 (1977). 